\title{
Effect of Foliar Applied Benzyladenine and Gibberellic Acid on Vegetative Growth and Chemical ConsTituents of Dracaena marginata. (B) Pinched Plants.
}

\author{
Mona A. Sorour ${ }^{1}$ and Nader A. El-Shanhorey ${ }^{2}$ \\ ${ }^{1}$ Ornamental Plants Research Department, Horticulture Research Institute, ARC, \\ Alexandria, Egypt. \\ 2Botanical Gardens Research Department, Horticultural Research Institute, ARC, \\ Alexandria, Egypt.
}

\begin{abstract}
The present study was carried-out at Antoniades Research Branch, Horticulture Research Institute, A.R.C. Alexandria, Egypt during the two successive seasons of 2013 and 2014. In this study, we aimed to test the effect of applying foliar sprays of gibberellic acid and benzyladenine in increasing the marketing quality of Dracaena marginata plants. Dracaena small plants were planted individually in $30 \mathrm{~cm}$ diameter plastic pots. The small plants were pinched to length to $30 \mathrm{~cm}$ from soil surface. The plants were sprayed with gibberellic acid at the concentrations of 500,1000 and $1500 \mathrm{mg} / \mathrm{L}$ and benzyladenine at the concentrations of 200,250 and $300 \mathrm{mg} / \mathrm{L}$. The obtained results showed that spraying with gibberellic acid at 1000 $\mathrm{mg} / \mathrm{L}$ and benzyladenine at $300 \mathrm{mg} / \mathrm{L}$ together increased significantly plant height, leaves number per plant, leaves dry weight, leaves area, stem diameter, stem dry weight, branches number per plant, root length and root dry weight. The obtained results showed that spraying with gibberellic acid at $1000 \mathrm{mg} / \mathrm{L}$ and benzyladenine at $250 \mathrm{mg} / \mathrm{L}$ together resulted in the highest chlorophyll content, carbohydrates content and nitrogen percentage in the leaves.
\end{abstract}

Key words: Dracaena marginata - gibberellic acid - benzyladenine.

\section{INTRODUCTION}

The genus Dracaena belongs to the botanical family Ruscaceae. Its center of origin is located in tropical and subtropical regions of Africa, Asia and Australia. This genus comprises about 40 species (Bailey and Bailey, 1976), but only six species $D$. deremensis, $D$. fragrans, $D$. marginata, $D$. reflexa, $D$. sanderiana, and $D$. surculosa (godseffiana) are cultivated as foliage plants. These species are favored as interior ornamental plants because of their diverse shapes, colors and forms available in the market and because of their ability to survive under low-light conditions with minimum care (Chen et al., 2002).

Plant growth regulators (cytokinins and gibberellins) are used in agricultural industry for stimulation and synchronization of flowering and fruit setting, promotion of rooting, reduction of vegetative growth, reduction of lodging of agronomic crops, or defoliation (Briant, 1974). Cytokinins are plant hormones that plants produce naturally and regulate plant growth, including cell division and leaf senescence. There are several commercial plant growth regulators (PGRs) that contain benzyladenine, a synthetic cytokinin (Padhye et al., 2008). It can be applied as a foliar spray or a substrate drench at different concentrations. The useful application concentration differs greatly between ornamental plants and is generally unknown (Werbrouk et al., 1996). The results Obtained with exogenous cytokinins, however, vary depending on the type and concentration of the cytokinins used (Bosse and Staden, 1989). 
Cytokinines appeared to play an important role in the regulation of cell division, differentiation and organogenesis in developing plants, enhancement of leaf expansion, nutrient mobilization and delayed senescence, (Skoog and Armstrong, 1970 and Hall, 1973). Gibberellins are commonly used as growth enhancers because they cause cell elongation in the plant. They can be used to partially overcome dormancy, increase flower size, flower number, flower uniformity, and to create standards. A gibberellin overdose will result in a spindly unmarketable plant (Runkle, 2006 and Leopold and Kriedmann, 1975).

Gibberellins are synthesized from mevalonic acid in young tissues of shoots and developing seeds (Davies, 1995). Transport is via both the xylem and the phloem. The effects of gibberellins vary by plant species. Some plant species respond with an increase in height due to an increase in cell length. Other plant species respond to gibberellins by increasing cell number as well as an increase in size, most likely cell length. Gibberellins prevent the development of lateral buds when applied to decapitated shoots of several species (Salisbury and Ross, 1969). The aim of this research is to study some important traits of Dracaena plants treated with gibberellic acid and benzyladenine on the marketing qualities.

\section{MATERIALS AND METHODS}

The present study was carried-out at Antoniades Research Branch, Horticulture Research Institute, A.R.C. Alexandria, Egypt during the two successive seasons of 2013 and 2014. On 10 th of March, 2013 and 2014 (in the first and second seasons, respectively) homogenous small plants of Dracaena marginata (34-36 cm height and 18-22 leaf per plant in average) were planted individually in plastic pots (30 cm diameter) filled with $8 \mathrm{~kg}$ mixture of sand and clay at the ratio of $(1: 1)$ by volume. The chemical constituents of the soil were measured as described by Jackson (1958) and illustrated in Table (1). On the $10^{\text {th }}$ of March in both seasons, the small plants were pinched to a length of 30 $\mathrm{cm}$ of the soil surface. Plants were sprayed with gibberellic acid at concentrations of 500,1000 and $1500 \mathrm{mg} / \mathrm{L}$ and benzyladenine at concentrations of 200,250 and $300 \mathrm{mg} / \mathrm{L}$, every 30 days starting from on $10^{\text {th }}$ of April till $10^{\text {th }}$ of July in both seasons. The control plants were sprayed with tap water. On $10^{\text {th }}$ of August in both seasons the plants were harvested.

Table (1). Chemical analysis of the used mixture soil for the two successive seasons of 2013 and 2014.

\begin{tabular}{lccccccccc}
\hline \multirow{2}{*}{ Season } & \multirow{2}{*}{$\mathbf{p H}$} & \multirow{2}{*}{$\left.\begin{array}{c}\text { EC } \\
(\mathbf{d S m}\end{array}{ }^{-1}\right)$} & \multicolumn{3}{c}{ Soluble cations (mg/l) } & \multicolumn{3}{c}{ Soluble anions (mg/l) } \\
\cline { 5 - 10 } & & $\mathbf{C a}^{++}$ & $\mathbf{M g}^{++}$ & $\mathbf{N a}^{+}$ & $\mathbf{K}^{+}$ & $\mathbf{H C O}_{3}{ }^{-}$ & $\mathbf{C l}^{-}$ & $\mathbf{S O}_{4}^{--}$ \\
\hline $\mathbf{2 0 1 3}$ & 8.24 & 1.80 & 1.7 & 0.9 & 1.6 & 0.65 & 1.3 & 1.38 & 1.10 \\
$\mathbf{2 0 1 4}$ & 8.08 & 1.61 & 1.3 & 0.6 & 1.4 & 0.53 & 1.0 & 1.13 & 0.98 \\
\hline
\end{tabular}

In both seasons, all plants received NPK chemical fertilization using fertilizer (Milagro Aminoleaf 20-20-20) at the rate of $2.0 \mathrm{~g}$ per pot each time. Fertilization was repeated every 30 days throughout the growing season (from 
the $20^{\text {th }}$ of March till the $20^{\text {th }}$ of July). In addition, weeds were removed manually upon emergence.

\section{Data were recorded as follows:}

\section{Vegetative growth parameters:}

Plant height $(\mathrm{cm})$, leaves number per plant, dry weight of leaves $(\mathrm{g})$, leaves area $\left(\mathrm{cm}^{2}\right)$, stem diameter $(\mathrm{cm})$, dry weight of stem $(\mathrm{g})$, branches number per plant, root length $(\mathrm{cm})$ and dry weight of root $(\mathrm{g})$.

\section{Chemical analysis determination:}

- Total chlorophylls content were determined according to Moran and Porath (1980).

- Carbohydrates contents of the leaves were determined according to Dubios et al. (1956).

- Nitrogen (\%) was determined in the digested solution by the modified microkjeldahl method as described by Pregl (1945).

The experimental design was a complete randomized block design (RCBD) contained 16 treatments with three replicates; each treatment contained three plants. Data were subjected to analysis of variance (ANOVA) using the SAS program, SAS Institute (Snedecor and Cochran, 1974) and the mean values were compared using L.S.D test at $5 \%$ level (SAS Institute, 2002).

\section{RESULTS}

\section{Vegetative growth}

\subsection{Plant height $(\mathrm{cm})$}

Data in Table (2) indicated that gibberellic acid and benzyladenine treatments had a significant effect on the plant height. In both seasons, plants sprayed with gibberellic acid at $1000 \mathrm{mg} / \mathrm{L}$ and benzyladenine at $300 \mathrm{mg} / \mathrm{L}$ together gave the tallest plant height compared to the control plants. As with other vegetative growth parameters, spraying the plants with gibberellic acid at $1000 \mathrm{mg} / \mathrm{L}$ and benzyladenine at $300 \mathrm{mg} / \mathrm{L}$ together gave the tallest plants 44.75 and $46.08 \mathrm{~cm}$ (in the first and second season, respectively).

\subsection{Number of leaves per plant}

Data presented in Table (2) showed that, the different gibberellic acid and benzyladenine treatments had a significant effect on the number of leaves per plant of Dracaena marginata plants. Plants sprayed using gibberellic acid at $1000 \mathrm{mg} / \mathrm{L}$ and benzyladenine at $300 \mathrm{mg} / \mathrm{L}$ together forming significantly larger leaves with a mean leaves number of 79.16 and 78.50 (in the first and second seasons, respectively). On the other hand, compared to that of control plants, the lowest number of leaves per plant was found to be 57.00 and 48.16 (in the first and second seasons, respectively).

\subsection{Leaves dry weight $(\mathrm{g})$ per plant}

Data presented in Table (2) also showed that spraying Dracaena marginata plants with gibberellic acid at $1000 \mathrm{mg} / \mathrm{L}$ and benzyladenine at 300 $\mathrm{mg} / \mathrm{L}$ together significantly increased the dry weight of leaves giving values of 
22.62 and $25.00 \mathrm{~g}$ per plant (in the first and second seasons, respectively), compared to the control 12.23 and $12.26 \mathrm{~g}$ per plant (in the first and second seasons, respectively). Accordingly, it can be seen from the data in Table (2) that Dracaena marginata plants sprayed with gibberellic acid at $1000 \mathrm{mg} / \mathrm{L}$ and benzyladenine at $300 \mathrm{mg} / \mathrm{L}$ together increased significantly leaves dry weight compared to other treatments.

\subsection{Leaves area $\left(\mathrm{cm}^{2}\right)$}

Data presented in Table (2) showed that the different gibberellic acid and benzyladenine treatments had a significant effect on leaves area of Dracaena marginata plants. Plants sprayed using gibberellic acid at $1000 \mathrm{mg} / \mathrm{L}$ and benzyladenine at $300 \mathrm{mg} / \mathrm{L}$ together formed significantly larger leaves (with a mean area of 3084.72 and $3064.38 \mathrm{~cm}^{2}$ (in the first and second seasons, respectively), than those formed by control plants 1356.72 and $1355.64 \mathrm{~cm}^{2}$ (in the first and second seasons, respectively).

Table (2). Average values of plant height and number, dry weight and area of leaves Dracaena marginata plants as influenced by benzyladenine (BA) and gibberellic acid (GA3) in the two seasons of 2013 and 2014.

\begin{tabular}{lcccccccc}
\hline \multirow{2}{*}{ Treatments (mg/L) } & \multicolumn{2}{c}{$\begin{array}{c}\text { Plant height } \\
\text { (cm) }\end{array}$} & \multicolumn{2}{c}{$\begin{array}{c}\text { Number Leaves } \\
\text { per } \text { plant }\end{array}$} & \multicolumn{2}{c}{$\begin{array}{c}\text { Dry weight of } \\
\text { leaves } \mathbf{( g )}\end{array}$} & \multicolumn{2}{c}{$\begin{array}{c}\text { Leaves area } \\
\text { (cm } \mathbf{c m}^{2} \text { ) }\end{array}$} \\
\cline { 2 - 9 } & $\mathbf{2 0 1 3}$ & $\mathbf{2 0 1 4}$ & $\mathbf{2 0 1 3}$ & $\mathbf{2 0 1 4}$ & $\mathbf{2 0 1 3}$ & $\mathbf{2 0 1 4}$ & $\mathbf{2 0 1 3}$ & $\mathbf{2 0 1 4}$ \\
\hline Control & 36.41 & 35.75 & 57.00 & 48.16 & 12.23 & 12.26 & 1356.72 & 1355.64 \\
GA500 & 40.66 & 39.25 & 69.33 & 69.33 & 16.26 & 17.79 & 2623.54 & 2479.95 \\
GA1000 & 41.00 & 39.58 & 70.16 & 70.33 & 18.19 & 18.85 & 2627.86 & 2561.79 \\
GA1500 & 41.91 & 40.25 & 70.66 & 71.16 & 18.72 & 19.04 & 2717.59 & 2711.61 \\
BA200 & 37.33 & 35.83 & 58.66 & 57.00 & 12.82 & 15.00 & 1766.58 & 1692.35 \\
BA250 & 36.58 & 37.75 & 64.66 & 61.33 & 13.25 & 15.44 & 1809.16 & 1728.10 \\
BA300 & 36.91 & 37.16 & 66.16 & 62.83 & 13.86 & 16.12 & 2008.39 & 1965.70 \\
GA500 + BA200 & 38.41 & 38.58 & 66.50 & 63.16 & 14.75 & 16.29 & 2171.86 & 2080.64 \\
GA500 + BA250 & 39.25 & 38.83 & 66.83 & 65.66 & 15.06 & 16.44 & 2273.99 & 2088.07 \\
GA500 + BA300 & 39.33 & 38.83 & 68.66 & 66.33 & 15.66 & 16.50 & 2309.69 & 2259.95 \\
GA1000 + BA200 & 42.25 & 40.83 & 77.50 & 74.83 & 21.66 & 20.24 & 3025.77 & 3019.17 \\
GA1000 + BA250 & 43.41 & 42.25 & 78.66 & 75.33 & 22.10 & 21.18 & 3030.35 & 3049.20 \\
GA1000 + BA300 & 44.75 & 46.08 & 79.16 & 78.50 & 22.62 & 25.00 & 3084.72 & 3064.38 \\
GA1500 + BA200 & 40.00 & 40.58 & 72.50 & 72.50 & 18.82 & 19.05 & 2802.09 & 2738.34 \\
GA1500 + BA250 & 41.00 & 40.58 & 75.66 & 73.33 & 19.61 & 19.34 & 2861.03 & 2882.88 \\
GA1500 + BA300 & 41.91 & 42.16 & 76.16 & 74.00 & 20.18 & 19.58 & 2996.29 & 2937.00 \\
\hline L.S.D. at 0.05 & $\mathbf{5 . 1 9}$ & $\mathbf{4 . 3 6}$ & $\mathbf{1 1 . 7 8}$ & $\mathbf{1 4 . 0 8}$ & $\mathbf{6 . 9 9}$ & $\mathbf{6 . 1 9}$ & $\mathbf{4 7 7 . 9 4}$ & $\mathbf{4 9 5 . 4 3}$ \\
\hline
\end{tabular}

\subsection{Stem diameter $(\mathrm{cm})$}

Data recorded in Table (3) showed that spraying Dracaena marginata plants with gibberellic acid at $1000 \mathrm{mg} / \mathrm{L}$ and benzyladenine at $300 \mathrm{mg} / \mathrm{L}$ together gave the largest stem diameter1.59 and $1.53 \mathrm{~cm}$ as compared with control treatment which gave 1.19 and $1.22 \mathrm{~cm}$ (in the first and second season, respectively). 


\subsection{Dry weight of stem (g)}

Data recorded in Table (3) showed that spraying Dracaena marginata plants with gibberellic acid at $1000 \mathrm{mg} / \mathrm{L}$ and benzyladenine at $300 \mathrm{mg} / \mathrm{L}$ together gave the heaviest values of stem dry weight 7.02 and $6.85 \mathrm{~g}$ (in the first and second seasons, respectively). Whereas, it was found that spraying with tap water (control) decreased the stem dry weight to 5.01 and $5.29 \mathrm{~g}$ as compared with other treatments.

\subsection{Number of branches per plant}

Data in Table (3) showed that plants sprayed with gibberellic acid at 1000 $\mathrm{mg} / \mathrm{L}$ and benzyladenine at $300 \mathrm{mg} / \mathrm{L}$ together formed the highest number of branches per plant which gave3.16 and 3.33 in the first and second seasons, respectively. Whereas, control plants gave the lowest number of branches per plant 1.00 and 1.00 (in the first and second season, respectively).

Table (3). Average values of diameter and dry weight of stem and number of branches of Dracaena marginata plants as influenced by benzyladenine (BA) and gibberellic acid (GA3) in the two seasons of 2013 and 2014.

\begin{tabular}{lcccccc}
\hline & \multicolumn{2}{c}{$\begin{array}{c}\text { Stem diameter } \\
\text { Treatments (mg/L) }\end{array}$} & \multicolumn{2}{c}{$\begin{array}{c}\text { Dry weight of } \\
\text { stem (g) }\end{array}$} & \multicolumn{3}{c}{$\begin{array}{c}\text { Number } \\
\text { branches } \\
\text { per }\end{array}$} \\
\cline { 2 - 7 } & $\mathbf{2 0 1 3}$ & $\mathbf{2 0 1 4}$ & $\mathbf{2 0 1 3}$ & $\mathbf{2 0 1 4}$ & $\mathbf{2 0 1 3}$ & $\mathbf{2 0 1 4}$ \\
\hline Control & 1.19 & 1.22 & 5.01 & 5.29 & 1.00 & 1.00 \\
GA500 & 1.34 & 1.38 & 5.95 & 6.16 & 1.00 & 1.50 \\
GA1000 & 1.36 & 1.39 & 6.06 & 6.23 & 1.50 & 1.83 \\
GA1500 & 1.37 & 1.40 & 6.08 & 6.27 & 1.16 & 1.66 \\
BA200 & 1.22 & 1.30 & 5.41 & 5.81 & 1.66 & 1.66 \\
BA250 & 1.27 & 1.32 & 5.64 & 5.92 & 2.16 & 2.33 \\
BA300 & 1.27 & 1.35 & 5.63 & 6.07 & 2.33 & 2.16 \\
GA500 + BA200 & 1.28 & 1.36 & 5.70 & 6.11 & 1.33 & 1.66 \\
GA500 + BA250 & 1.32 & 1.37 & 5.86 & 6.13 & 1.50 & 2.00 \\
GA500 + BA300 & 1.32 & 1.37 & 5.88 & 6.14 & 1.66 & 1.83 \\
GA1000 + BA200 & 1.50 & 1.44 & 6.65 & 6.45 & 2.00 & 2.00 \\
GA1000 + BA250 & 1.52 & 1.52 & 6.74 & 6.83 & 3.00 & 3.16 \\
GA1000 + BA300 & 1.59 & 1.53 & 7.02 & 6.85 & 3.16 & 3.33 \\
GA1500 + BA200 & 1.47 & 1.42 & 6.50 & 6.32 & 1.66 & 1.66 \\
GA1500 + BA250 & 1.46 & 1.43 & 6.52 & 6.39 & 2.33 & 3.00 \\
GA1500 + BA300 & 1.49 & 1.43 & 6.58 & 6.43 & 2.50 & 3.16 \\
\hline L.S.D. at 0.05 & $\mathbf{0 . 1 5}$ & $\mathbf{0 . 1 8}$ & $\mathbf{0 . 6 9}$ & $\mathbf{0 . 8 0}$ & $\mathbf{0 . 5 0}$ & $\mathbf{0 . 5 7}$ \\
\hline
\end{tabular}

1.8. Root length $(\mathrm{cm})$

Data recorded in Table (4) showed that spraying Dracaena marginata plants with gibberellic acid at $1000 \mathrm{mg} / \mathrm{L}$ and benzyladenine at $300 \mathrm{mg} / \mathrm{L}$ together gave the highest values of root length 116.80 and $114.18 \mathrm{~cm}$ as compared with control treatment which gave 95.19 and $87.12 \mathrm{~cm}$ (in the first and second season, respectively). 


\subsection{Dry weight of root $(\mathrm{g})$}

Data recorded in Table (4) showed that spraying Dracaena marginata plants with gibberellic acid at $1000 \mathrm{mg} / \mathrm{L}$ and benzyladenine at $300 \mathrm{mg} / \mathrm{L}$ together gave the largest root dry weight 6.31 and $5.91 \mathrm{~g}$ (in the first and second seasons, respectively). Whereas, it was found that spraying with tap water (control) decreased the root dry weight to 3.78 and $3.93 \mathrm{~g}$ (in the first and second seasons, respectively).

Table (4). Average values of root length and root dry weight of Dracaena marginata plants as influenced by benzyladenine (BA) and gibberellic acid (GA3) in the two seasons of 2013 and 2014.

\begin{tabular}{lcccc}
\hline \multirow{2}{*}{ Treatments (mg/L) } & \multicolumn{2}{c}{$\begin{array}{c}\text { Root length } \\
(\mathbf{c m})\end{array}$} & \multicolumn{2}{c}{$\begin{array}{c}\text { Dry weight of } \\
\text { root } \mathbf{( g )}\end{array}$} \\
\cline { 2 - 5 } & $\mathbf{2 0 1 3}$ & $\mathbf{2 0 1 4}$ & $\mathbf{2 0 1 3}$ & $\mathbf{2 0 1 4}$ \\
\hline Control & 95.19 & 87.12 & 3.78 & 3.93 \\
GA500 & 106.32 & 96.80 & 4.79 & 4.70 \\
GA1000 & 106.98 & 97.46 & 5.09 & 4.85 \\
GA1500 & 109.38 & 99.44 & 5.13 & 5.00 \\
BA200 & 97.59 & 88.44 & 4.09 & 4.35 \\
BA250 & 95.84 & 93.06 & 4.33 & 4.38 \\
BA300 & 95.84 & 91.74 & 4.34 & 4.45 \\
GA500 + BA200 & 100.43 & 95.70 & 4.43 & 4.54 \\
GA500 + BA250 & 102.61 & 95.92 & 4.49 & 4.65 \\
GA500 + BA300 & 103.05 & 95.92 & 4.55 & 4.67 \\
GA1000 + BA200 & 110.47 & 101.20 & 5.78 & 5.49 \\
GA1000 + BA250 & 113.75 & 104.28 & 5.90 & 5.55 \\
GA1000 + BA300 & 116.80 & 114.18 & 6.31 & 5.91 \\
GA1500 + BA200 & 104.36 & 100.10 & 5.26 & 5.13 \\
GA1500 + BA250 & 106.98 & 100.32 & 5.29 & 5.27 \\
GA1500 + BA300 & 109.38 & 104.28 & 5.61 & 5.33 \\
\hline L.S.D. at 0.05 & $\mathbf{1 3 . 8 1}$ & $\mathbf{1 0 . 7 9}$ & $\mathbf{1 . 8 4}$ & $\mathbf{1 . 6 5}$ \\
\hline
\end{tabular}

\section{Chemical constituents}

\subsection{Total chlorophylls content (mg/g F.W)}

The results of leaf chemical analysis in Table (5) also showed that the gibberellic acid and benzyladenine treatments had clear effect on the total chlorophylls content. The recorded mean values ranged from 2.39 and 2.40 $\mathrm{mg} / \mathrm{g}$ in the first and second seasons, respectively, in plants sprayed with gibberellic acid at $1000 \mathrm{mg} / \mathrm{L}$ and benzyladenine at $250 \mathrm{mg} / \mathrm{L}$ together to 1.95 and $1.99 \mathrm{mg} / \mathrm{g}$ in the first and second seasons, respectively, in plants sprayed with tap water (control).

\subsection{Total carbohydrates content (\%)}

The results in Table (5) also showed that most of the tested gibberellic acid and benzyladenine concentrations increased the mean total carbohydrates in the leaves of Dracaena marginata plants, compared to the control. Among the plants receiving the different treatments, plants sprayed with gibberellic acid at $1000 \mathrm{mg} / \mathrm{L}$ and benzyladenine at $250 \mathrm{mg} / \mathrm{L}$ together had the highest 
carbohydrates in leaves of 19.36 and $19.50 \%$ (in the first and second seasons, respectively).

\subsection{Nitrogen percentage in leaves (\%)}

The results in Table (5) also show that the mean nitrogen content of the leaves was slightly increased by spraying the plants with gibberellic acid at $1000 \mathrm{mg} / \mathrm{L}$ and benzyladenine at $250 \mathrm{mg} / \mathrm{L}$ together which gave nitrogen contents of 2.29 and $2.34 \%$ (in the first and second seasons, respectively), compared to the control. The lowest values 1.88 and $1.94 \%$ (in the first and second seasons, respectively), were recorded in plants sprayed with tap water (control).

Table (5). Average of chemical constituents of Dracaena marginata plants as influenced by benzyladenine (BA) and gibberellic acid (GA3) in the two seasons of 2013 and 2014.

\begin{tabular}{lcccccc}
\hline & \multicolumn{2}{c}{$\begin{array}{c}\text { Chlorophyll } \\
\text { content }\end{array}$} & \multicolumn{2}{c}{$\begin{array}{c}\text { Carbohydrates } \\
\text { Content in }\end{array}$} & \multicolumn{2}{c}{$\begin{array}{c}\text { Nitrogen } \\
\text { content } \\
\text { Treatments (mg/L) }\end{array}$} \\
& \multicolumn{2}{c}{ (mg/g F.W) } & \multicolumn{2}{c}{ leaves (\%) D.W } & \multicolumn{2}{c}{ (\%) } \\
\cline { 2 - 7 } & $\mathbf{2 0 1 3}$ & $\mathbf{2 0 1 4}$ & $\mathbf{2 0 1 3}$ & $\mathbf{2 0 1 4}$ & $\mathbf{2 0 1 3}$ & $\mathbf{2 0 1 4}$ \\
\hline Control & 1.95 & 1.99 & 15.86 & 16.17 & 1.88 & 1.94 \\
GA500 & 2.05 & 2.05 & 16.64 & 16.66 & 1.97 & 2.00 \\
GA1000 & 2.10 & 2.15 & 17.05 & 17.46 & 2.02 & 2.10 \\
GA1500 & 2.08 & 2.09 & 16.85 & 16.97 & 2.00 & 2.04 \\
BA200 & 2.03 & 2.04 & 16.50 & 16.57 & 1.96 & 1.99 \\
BA250 & 2.12 & 2.12 & 17.21 & 17.20 & 2.04 & 2.07 \\
BA300 & 2.09 & 2.07 & 16.98 & 16.82 & 2.01 & 2.02 \\
GA500 + BA200 & 2.14 & 2.16 & 17.39 & 17.60 & 2.06 & 2.11 \\
GA500 + BA250 & 2.38 & 2.38 & 19.31 & 19.36 & 2.30 & 2.32 \\
GA500 + BA300 & 2.28 & 2.29 & 18.47 & 18.59 & 2.19 & 2.23 \\
GA1000 + BA200 & 2.16 & 2.17 & 17.51 & 17.64 & 2.08 & 2.12 \\
GA1000 + BA250 & 2.39 & 2.40 & 19.36 & 19.50 & 2.29 & 2.34 \\
GA1000 + BA300 & 2.18 & 2.27 & 17.72 & 18.44 & 2.10 & 2.21 \\
GA1500 + BA200 & 2.20 & 2.21 & 17.84 & 17.93 & 2.12 & 2.15 \\
GA1500 + BA250 & 2.30 & 2.33 & 18.67 & 18.93 & 2.21 & 2.27 \\
GA1500 + BA300 & 2.22 & 2.28 & 18.00 & 18.55 & 2.14 & 2.22 \\
\hline L.S.D. at 0.05 & $\mathbf{0 . 0 6}$ & $\mathbf{0 . 0 5}$ & $\mathbf{0 . 4 7}$ & $\mathbf{0 . 4 4}$ & $\mathbf{0 . 0 6}$ & $\mathbf{0 . 0 5}$ \\
\hline
\end{tabular}

\section{DISCUSSION}

Results of this study and other studies confirm that gibberellic acid and benzyladenine increase some process such as cell wall tension and thus cell water potential decline (Fathi and Esmaeelpoor, 1999) and more water absorption to cell and at last increase fresh weight succulence (Mutui et al., 2001 and Emongor and Tshwenyane, 2004). On the other hand effect of gibberellic acid and benzyladenine on increasing of carbohydrate hydrolysis induction cause to stability of respiration (De-Hortogh, 1996). Effect of gibberellic acid and benzyladenine on preventing of senescence (Pun et al., 1999, Ranwala and Miller, 2000 and Emongor and Tshwenyane, 2004) and its effect on chlorophyll synthesis and chloroplast development increasing 
prevent from leaves yellowing (Guo et al., 2003 and Emongor and Tshwenyane, 2004). Thus, gibberellic acid interferes in retard chlorophyll destroy. Therefore, a section of this effect is caused to chlorophyll preservation that is attendant with leaf nitrogen level preservation.

It has been known that the use of growth regulators in agriculture practices is most favourable for promoting and improving plant-growth of different plants. The beneficial effect of gibberellic acid on different plants were recorded by (Shedeed et al., 1991) on croton plant, (Eraki, 1994a) on Queen Elizabeth rose plants, (Bedour et al., 1994) on Ocimum basillicum. They concluded that gibberellic acid is used for regulating plant growth through increasing cell division and cell elongation. The effect of cytokinins, especially benzyl adenine, on the plant growth and chemical constituents of different plants have mentioned by (Eraki et al., 1993) on salvia plants, (Mazrou, 1992) on Datura, (Mazrou et al., 1994) on sweet basil, (Mansoure et al., 1994) on soybean plants and (Vijayakumari, 2003) on Andrographis panculata. Cytokinins are important plant hormones that regulate various processes of plant growth and development including cell division and differentiation, enhancement of leaf expansion and nutrient mobilization (Hassan and ElQuesni, 1989 and Shudok, 1994). The response of plants to cytokinins have been also discussed in more papers such as (Eraki, 1994b) on Hibiscus sabdarijfa L. plants who mentioned that application of BA significantly increased plant height, number of branches as well as fresh and dry weights of leaves than the control. Hassanein (1985) on Pelargonium graveolens, (El-Sayed et al., 1989) on Polianthus tuberosa, (Menesi et al., 1991) on Calendula officinalis and (Mazrou et al., 1994) on sweet basil, found that foliar application of BA increased growth of different organs, active constituents production of these plants and increased total carbohydrates content on comparison to the untreated plants.

According to these points, necessity of using growth regulator to improve marketing quality is completely justified. Among treatments that we used in this study, gibberellic acid $1000 \mathrm{mg} / \mathrm{L}$ with benzyladenine $300 \mathrm{mg} / \mathrm{L}$ showed good results and their means did not have significant difference with each other, but they showed significant difference with other treatments. Gibberellic acid 1000 $\mathrm{mg} / \mathrm{L}$ with benzyladenine $300 \mathrm{mg} / \mathrm{L}$ gave the best plant height, number of leaves per plant, dry weight of leaves, leaves area, stem diameter, dry weight of stem, number of branches per plant, root length and dry weight of root which significant differences with other treatments. Similar increase in the vegetative growth was recorded by (Shedeed et al., 1991) on croton plants, (Rahman et al., 2004) on soybean, (Soad, 2005) on Jajoba plants, (Rawia and Bedour, 2006) on croton plants and (Soad et al., 2010) on croton plants.

Gibbberellic acid at $1000 \mathrm{mg} / \mathrm{L}$ with benziladenine at $250 \mathrm{mg} / \mathrm{L}$ together were the most effective treatment on total chlorophyll, carbohydrates and nitrogen content. This treatment was significantly different with control respecting to total chlorophyll and was significantly different with control. Similar results in the chlorophylls content reported by (Shedeed et al., 1991) on croton plants, (Mousa et al., 2001) on Nigella sativa, (Rawia and Bedour, 2006) on 
croton plants, (Soad et al., 2010) on croton plants and (Majidian et al., 2012) on Zantedesehia aethiopied. Similar results in the carbohydrates content reported by (Sheren, 2005) on flax plants, (Rawia and Bedour, 2006) on croton plants, (Nahed, 2007) on croton plants and (Soad et al., 2010) on croton plants. Similar results in the nitrogen content reported by (Sayed, 2001) on Khaya senegalensis, (Mohammed, 2003) on Acacia saligna, (Soad, 2005) on Jajoba plants, (Rawia and Bedour, 2006) on croton plants, (Nahed, 2007) on croton plants and (Soad et al., 2010) on croton plants.

\section{CONCLUSIONS}

The present results reported about the vegetative growth parameters and chemical compositions of Dracaena marginata showed that the best spraying treatments of gibberellic acid at $1000 \mathrm{mg} / \mathrm{L}$ and benzyladenine at $300 \mathrm{mg} / \mathrm{L}$ together gave the best quality results for plant height, number of leaves, leaves area, stem diameter, branches number and root length of Dracaena marginata pinched plants.Generally, the results obtained to sprayed Dracaena marginata plants with gibberellic acid and benzyladenine together better than spraying dracaena plants with gibberellic acid or benzyl adenine alone enhanced good vegetative growth and some chemical components of plants Dracaena marginata plants.

\section{REFERENCES}

Bailey, L. H. and E. Z. Bailey. (1976). Hortus Third: A Concise Dictionary of Plants Cultivated in the United States and Canada. McMillan Publishing Co., Inc., New York, USA.

Bedour, H. Abou-Leila, M. S. Aly and N.F. Abdel-Hady. (1994). Effect of foliar application of $\mathrm{GA}_{3}$ and $\mathrm{Zn}$ on Ocimum basillicum L. grown in different soil type. Egypt. J. Physiol. Sci., 18:365-380.

Bosse, C.A. and J. Staden. (1989). Cytokinins in cut carnation flowers. Effects of cytokinin type, concentration and mode of application on flower longevity. J. Plant Physiol, 135: 155-159.

Briant, R.E. (1974). An analysis of the effects of gibberellic acid on tomato leaf growth. Journal. expermintal. Bot. 25:764-771.

Chen, J., R. J. Henny and D.B. McConnell. (2002). Development of new foliage plant cultivars. J. Janick and A. Whipkey (eds.), Trends in new crops and new uses. ASHS Press, Alexandra, VA, p. 466-472.

Davies, P.J. (1995). Plant Hormones, Physiology, Biochemistry, and Molecular Biology. - Kluwer Academic Publishers, Dordrecht.

De-Hortogh, A. (1996). Marketing and research requirements for Lilium in North America. ActaHorticulturae, 414: 17-24.

Dubios, M., K. Gilles, J. Hamlton, P. Rebers and F. Smith. (1956). Colourimetric method for determination of sugars and related substances. Analytical Chemistry, 28(3): 350- 356.

El-Sayed, A.A., M.A. Salem and E.I. El-Maadawy. (1989). Effect of gibberellic acid (GA3) and benzyladenine (BA) on Polianthus tuberosa L.J. Agric. Res. TantaUniv., 15, 301-311.

Emongor, V. and S.O. Tshwenyane. (2004). Effect of accel on the postharvest vase life of Easter lily. Agric. Sci., 3: 170-174. 
Eraki, M.A. (1994a). The effect of gibberellic application and chelated iron nutrition on the growth and flowering of Queen Elizabeth rose plants. The first Conf. of Ornamental Hort. 2:436-444.

Eraki, M.A. (1994b). Effect of benzyladenine (BA) application on the growth, fruit yield and some chemical constituents of Hibiscus sabdariffa L. plants. Minofiya J. Agric. Res., 2:623-637.

Eraki, M.A., M.M. Mazrou and M.M. Afify. (1993). Influence of kinetin and indole3-acetic acid (IAA) on the growth, drug yield and essential oil content of Salvia officinalis L. plant. Zagazig Journal. Agriculture. Research. 20:1233-1239.

Fathi, G.h., and B. Esmaeelpoor. (1999). Plant growth regulators. Jahade daneshgahi Mashhad, pp: 288.

Guo, W., L. Zheng, Z. Zheng and W. Zheng. (2003). Phytohormones regulate senescence of cut chrysanthemum. Acta Hort., 624: 349-355.

Hall, R.H. (1973). Cytokinins as a probe of development processes. Ann. Rev. Plant Physiology, 24:415-444.

Hassan, E.A. and F.M. El-Quesni. (1989). Application of growth regulators in agriculture. A cytokinin induced new morphogenetic phenomena in carnation (Dianthus caryophyllus L). Bull. Fac. Agric, Cairo Univ., 40:187196.

Hassanein, M.A. (1985). Effect of some growth regulators and potassium feritilizers on growth, yield and essential oil production of geranium plants (Pelargonium graveolens L). M. Sc. Thesis, Fac. Agric, Cairo University.

Jackson, N. L. (1958). Soil Chemical Analysis. Constable. Ltd. Co., London, $498 \mathrm{p}$.

Leopold, A. C. and P. E. Kriedmann. (1975). Plant Growth and Development. Sec. Edit., McGraw ittil Book Co., New York, NY. 545p.

Majidian, N., A. Nadari and M. Majidian. (2012). The effect of four levels of GA3 and BA on The quantitative and qualitative characteristics of Zantedeschia aethiopica cv. Childsiana Pot Plant. 25(4):361-368.

Mansoure, F.A., O.A. El-Shahaby, H.A.M. Mostafa, A.M. Gaber and A.A. Ramadan. (1994). Effect of Benzyladenine on growth, pigments and productivity of soybean plant. Egypt Journal Physiology Science. 18, 245-364.

Mazrou, M.M. (1992). The growth and tropane alkaloids distribution on the different organs of Datura innoxia Mill. plant on relation to benzyl adenine (BA) application. Monofiya Journal. Agriculture Research. 17, 1971-1983.

Mazrou, M.M., M.M. Afify, S.A. El-Kholy and G.A. Morsy. (1994). Physiological studies on Ocimum basillicum plant. I. Influence of kinetin application on the growth and essential oil content. Menofiya J. Agric. Res., 19:421-434.

Menesi, F.A., E.M.S. Nofal and E.M. El-Mahrouk. (1991). Effect of some growth regulators on Calendula officinalis L. Egypt. J. Applied Sci., 6, 115.

Mohammed, S.H. (2003). Evaluation and physiological studies on some woody plants. Ph.D. Thesis Dissertation, Fac. Of Agric., Minia Univ., Egypt.

Moran, R. and D. Porath. (1980). Chlorophyll Determination in Intact Tissues Using N,N-Dimethyl formamide. Department of Botany, The Geovge. S. 
Wise faculty for life sciences, Tel Aviv University, Ramat Aviv, Israel Plant Physiol., 65: 478- 479.

Mousa, G.T., I.H. El-Sallami and E.F. Ali. (2001). Response of Nigella sativa L. to foliar application of gibberellic acid, benzyladenine, iron and zinc. Assiut J. Agric. Sci., 32: 141-156.

Mutui, T.M., V.E. Emongor and M.J. Hutchinson. (2001). Effect of Accel on the vase life and postharvest quality of (Alestroemeria aurantiaca L.) cut flowers. Afric. J. Sci. Technol., 2: 82-88.

Nahed, G. Abd El-Aziz. (2007). Stimulatory effect of NPK fertilizer and benzyladenine on growth and chemical constituents of Codiaeum variegatum L. plant. American-Eurasian J. Agric. and Environ. Sci., 2(6): 711-719.

Padhye, S., E. Runkle, M. Olrich and L. Reinbold. (2008). Improving branching and postharvest quality. Greenhouse Prod. News 18(8):36-42.

Pregl, F. (1945). Quantitative Organic Micro Analysis. $4^{\text {th }}$ Ed. J. A. Churchil. Ltd., London, $539 \mathrm{p}$.

Pun, U.K., R.N. Rowe, J.H. Rowarth, M.F. Barnes, C. Dawson and J.A. Oheyes. (1999). Influence of ethanol on climateric senescence in five cultivars of gladiolus. New Zealand. J. Crop. Hort. Sci., 27: 69-77.

Rahman, M.S., N.I.M. Taher and M.A. Karim. (2004). Influence of GA3 and $\mathrm{MH}$ and their time of spray on dry matter accumulation and growth attributes of soybean. Pak. J. Biol. Sci., 7:1851-1857.

Ranwala, A.P. and W.B. Miller. (2000). Preventing mechanism of gibberellins $4+7$ and light on low-temperature-induced leaf senescence in Lilium cv. stargazer. Postharvest Biology and Technology, 19: 85-92.

Rawia, A. Eid and Bedour H. Abou-Leila. (2006). Response of croton plants to gibberellic acid, benzyladenine and ascorbic acid application. World J.Agric. Sci., 2(2):174-179.

Runkle, E. (2006). Recovering from a PGR overdose. In Greenhouse Product News. p: 78.

Salisbury, F.B. and C. Ross. (1969). Plant Physiology. Wadsworth Publishing Co. Inc., Belmont, CA., USA.

SAS Institute. (2002). SAS user guide and program 20 version 9.0.38.cary, NC27513.

Sayed, R.M. (2001). Effect of some agricultural treatments on the growth and chemical composition of some woody tree seedlings. Ph.D. Thesis Dissertation, Fac. Of Agric., Minia Univ., Egypt.

Shedeed, M.R., K.M. El-Gamassy, M.E. Hashim and A.M.N. Almulla. (1991). Effect of fulifirtil fertilization and growth regulators on the vegetative growth of croton plants. Annals Agric.Sci.,Ain Shams Univ. Cairo, Egypt, 36:209-216.

Sheren, A. S. N. (2005). Some physiological studies on flax plant. Ph.D. Thesis Fac.Agric., Cairo Univ., Egypt.

Shudok, K. (1994). Chemistry of phenylurea cytokinins. In Cytokinins: Chemistry, activity and function Mokk, D.V. and Mc Mok (Eds.). CRC Press, Boca Raton., 35-42 p.

Skoog, F. and D.J. Armstrong. (1970). Cytokinins. Ann. Rev. Plant Physilogy, 21:359-384. 
Snedecor, G. and W. Cochran. (1974). Statistical Methods.7 Ed. The lowa state Univ. Press, Ames,lowa,USA, ISBN 9780815381560, 97808153815602.

Soad, M.M. Ibrahim. (2005). Response of vegetative growth and chemical composition of jojoba seedlings to some agricultural treatments. Ph.D. Thesis, Fac. of Agric., Minia Univ., Egypt.

Soad, M.M. Ibrahim, Lobna S. Taha and M.M. Farahat. (2010).Vegetative growth and chemical constituents of croton plants as affected by foliar application of benzyladenine and gibberellic acid. Journal of American Science, 6(7):126-130.

Vijayakumari, B. (2003). Influence of foliar spray by GA3 and IAA on the growth attributes of Andrographis paniculata L. Journal of Phytological Research Physiological Society, Bharatpur, India, 12:161-163.

Werbrouk, S.P.O., P. Redig, A. Van Onckelen and P.C. Debergh. (1996). Gibberellins play a role in the interaction between imidazole fungicides and cytokinins in Araceae. J. Plant Growth Regul, 15, pp. 87-93.

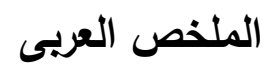

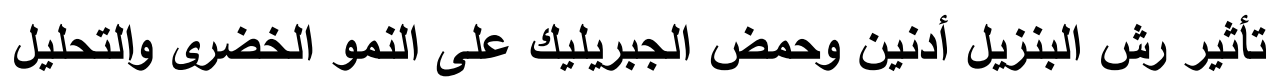

الكيماوى فى الدراسينا مارجيناتا. (ب) النباتات المطوشة

$$
\text { منى عبد الحميد سرور'، نادر أحمد الشنهورى }
$$

' فرع بحوث نباتات الزينة بأنطونيادس - الإسكندرية- معهد بحوث البساتين - مركز البحوث الزراعية ץ فرع بحوث الحدائق النباتية بأنطونيادس- الإسكندرية- معهد بحوث البساتين - مركز البحوث الزراعية

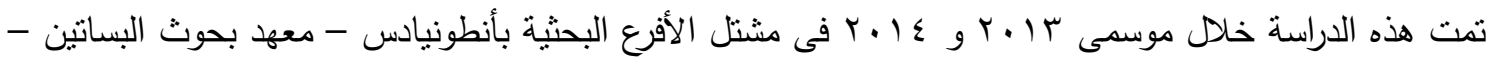

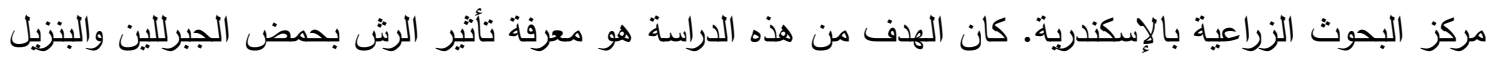

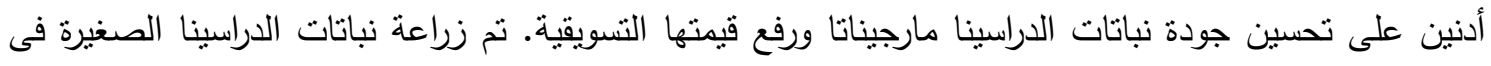

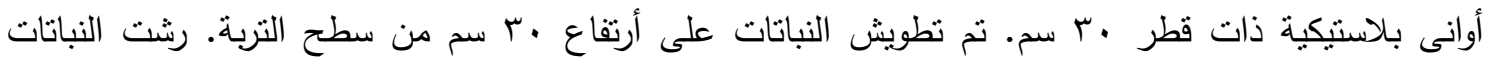

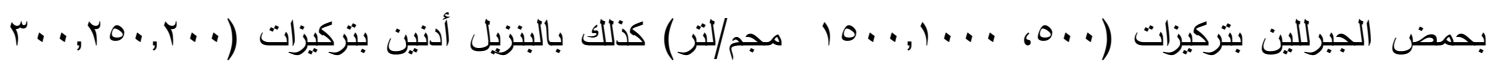

وكانت النتائج المتحصل عليها أظهرت أن رش نباتات الدراسينا بحمض الجبرللين ... . 1 مجم/لتر

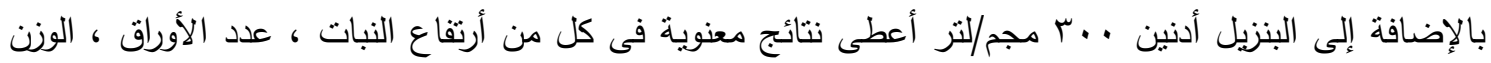

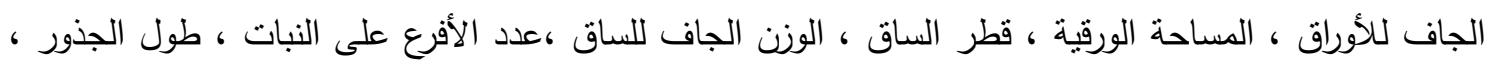

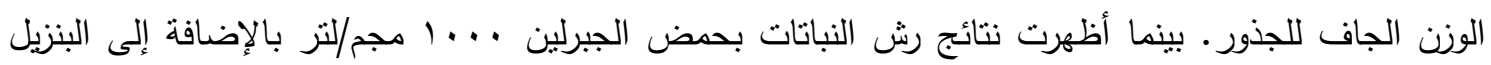

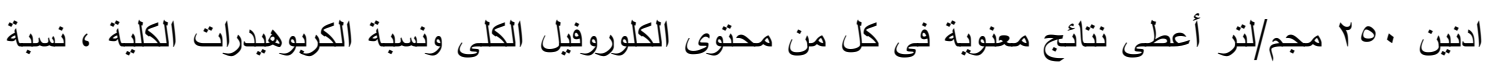
النيتزوجين فى الأوراق. 